Meta

Journal des traducteurs

Translators' Journal

\title{
The Political Translations of Monteiro Lobato and Carlos Lacerda
}

\section{John Milton et Eliane Euzebio}

Volume 49, numéro 3, septembre 2004

L'histoire de la traduction et la traduction de l'histoire History of Translation and Translation of History

URI : https://id.erudit.org/iderudit/009374ar

DOI : https://doi.org/10.7202/009374ar

Aller au sommaire du numéro

Éditeur(s)

Les Presses de l'Université de Montréal

ISSN

0026-0452 (imprimé)

1492-1421 (numérique)

Découvrir la revue

Citer cet article

Milton, J. \& Euzebio, E. (2004). The Political Translations of Monteiro Lobato and Carlos Lacerda. Meta, 49(3), 481-497. https://doi.org/10.7202/009374ar
Résumé de l'article

Cet article examine le lien entre la traduction et la politique, en se concentrant sur une époque spécifique de l'histoire brésilienne, soit la dictature de Getúlio Vargas, de 1930 à 1945, et de 1950 à 1954. Premièrement, l'étude examine les liens entre la politique fiscale et la traduction. Ensuite, elle analyse les traductions, ou plutôt les adaptations de Peter Pan et Don Quijote, par l'écrivain et l'éditeur, Monteiro Lobato. La dernière section décrit la situation autour de la traduction de Julius Caesar de Shakespeare par l'homme politique brésilien, Carlos Lacerda, gouverneur de l'état de Guanabara (grande Rio de Janeiro) (1960-1965). 


\title{
The Political Translations of Monteiro Lobato and Carlos Lacerda
}

\author{
JOHN MILTON AND ELIANE EUZEBIO \\ University of São Paulo, Brazil \\ jmilton@usp.br
}

\begin{abstract}
RÉSUMÉ
Cet article examine le lien entre la traduction et la politique, en se concentrant sur une époque spécifique de l'histoire brésilienne, soit la dictature de Getúlio Vargas, de 1930 à 1945, et de 1950 à 1954. Premièrement, l'étude examine les liens entre la politique fiscale et la traduction. Ensuite, elle analyse les traductions, ou plutôt les adaptations de Peter Pan et Don Quijote, par l'écrivain et l'éditeur, Monteiro Lobato. La dernière section décrit la situation autour de la traduction de Julius Caesar de Shakespeare par l'homme politique brésilien, Carlos Lacerda, gouverneur de l'état de Guanabara (grande Rio de Janeiro) (1960-1965).
\end{abstract}

\section{ABSTRACT}

This article examines the connection between translation and politics, concentrating on a specific period in Brazilian history, the dictatorship of Getúlio Vargas, from 1930 to 1945 , and then from 1950 to 1954. It initially looks at the link between fiscal policy and translation. It then analyzes the translations, or rather, adaptations, of Peter Pan and Don Quixote, by the Brazilian writer and publisher, Monteiro Lobato. The final section of the paper will describe the situation surrounding the translation of Shakespeare's Julius Caesar by the Brazilian politician, Carlos Lacerda, governor of the state of Guanabara (greater Rio de Janeiro) (1960-1965).

\section{MOTS-CLÉS/KEYWORDS}

Brazilian history, fiscal policy, political translation, Monteiro Lobato, Carlos Lacerda

\section{Introduction}

This article will look at different aspects of the connection between translation and politics, concentrating on translations which were carried out during and immediately after the dictatorship of Getúlio Vargas in Brazil from 1930 to 1945, and then from 1950 to 1954. Initially, the connection between government fiscal policy and translation will be analyzed. Then the translations, or rather, adaptations, of Peter Pan and Don Quixote, by the Brazilian writer and publisher, Monteiro Lobato, will be studied. The final section of the paper will describe the situation surrounding the translation of Shakespeare's Julius Caesar by the Brazilian politician, Carlos Lacerda, governor of the state of Guanabara (greater Rio de Janeiro) (1960-1965).

\section{Fiscal Policy and Translation}

One of the most important political axes in Brazilian history has been that of nationalistic protectionists, in favour of high tariff barriers for imported goods, versus internationalists, those who believe in low tariff barriers for foreign goods, that Brazil 
should take its place in the world market. Traditionally, the coffee "barons," based in the state of São Paulo, feared reprisals from their major markets in Europe and North America if Brazil increased tariff barriers on manufactured goods, and demanded free trade. However, in recent years, as Brazil has become an industrial power, the importance of coffee in the Brazilian economy has been much less. In recent months, this discussion has centred on the benefits of Brazil joining the FTAA (the Free Trade Area of the Americas).

The protectionist nationalist government of the 1930s aimed at developing Brazilian industries to substitute foreign imports. Thus high tariffs were placed on most imported goods, including books and paper. Yet the equation is slightly more complicated. In 1918, Monteiro Lobato, when he was beginning his publishing career, criticized the Brazilian government for the low tariffs on imported books, whereby imported books were often cheaper than their Brazilian counterparts, and, through a special agreement and a need to supply the small market for technical and scientific works, all books imported from Portugal were untaxed. As a publisher, Lobato naturally wished his books to compete favourably with imported works and favoured high tariffs on imported works.

However, he was at the same time in favour of low tariffs on imported paper. The fledgling Brazilian paper industry, which had a powerful lobby, needed to import expensive machinery and cellulose and did not have the technical expertise to produce high quality paper. So Lobato wanted cheaper and better quality imported paper but did not want the competition of cheap imported books.

High tariffs on nearly all imported goods were introduced after 1930, when Getúlio Vargas' nationalist insurgents defeated the forces of the República Velha, and were very successful in developing the Brazilian publishing industry, yet, in the main, the Brazilian book industry had to use low quality Brazilian-produced paper, which was more expensive to produce than foreign paper.

Book production increased substantially in the 1930s and continued increasing right through the period of the Second World War. Government policies had considerable effects on the book industry: a reform of basic education resulted in greater demand for school textbooks; and the devaluation of the currency, the mil-réis (1930-31), resulted in imported books becoming, for the first time, more expensive than those published in Brazil. This helped to increase the number of translations and reduce the number of imported French books, and also increase exports of books from Brazil to Portugal. Moreover, the precarious copyright situation of the period enabled publishers to openly infringe on copyright laws, thus allowing for multiple translations of the same volume, which could be aimed at different markets.

Translations of successful literary works were usually a sound investment. If the work was in the public domain, then royalties were zero, and the chances of the foreign work being accepted by the Brazilian public which had always looked abroad were much better than those of a book written by an unknown Brazilian author.

The Instituto Nacional do Livro was set up by the Getúlio Vargas government to improve the distribution of books to public libraries. It reissued out-of-print classic Brazilian works and planned to publish the Enciclopédia Brasileira, a project which was based on the Italian encyclopaedia, Triccani, which had been published under the auspices of Mussolini. However, this final project never got off the ground. 
Adriana Pagano (2001) details the growth of a number of important private publishing houses in both countries which were established during the 1930s in both Argentina and Brazil: Editora Globo, Companhia Editora Nacional, Martins, and José Olympio in Brazil, and Sudamericana, Losada, Emecé, and Claridad in Argentina.

The period from 1930 to 1950 saw both in Brazil and Argentina a growing process of industrialization and urbanization. The labour market was expanding, allowing for a rise in the purchasing power of those who had hitherto had little access to consumer goods. A rise in people's personal income therefore meant a rise in consumption. The changes in the educational policies adopted by the government to improve basic education and literacy already mentioned led to a rising number of literate people and hence of potential readers of books and magazines. Other sources of consumption involved new forms of mass media such as the cinema and the radio.

Both in Argentina and Brazil a large number of collections were issued, appealing to the new lower-middle-class reader who possessed little cultural capital, and who did not know foreign languages. The books translated and published for this new reader were generally for leisure purposes, often tie-ins with Hollywood films, in addition to feuilleton novels, translated soap opera scripts, adapted screenplays, comics and cartoons.

A large number of collections were published in both countries with titles like "Grandes Novelistas" [Great Novel Writers], "Grandes Ensaístas" [Great Essayists], "Os Grandes Livros Brasileiros” [Great Brazilian Books], "Obras Primas Universais” [Universal Masterpieces], "Novelistas Americanos Contemporâneos” [Contemporary Novel Writers of the Americas], "Biblioteca de Obras Famosas" [Library of Famous Books].

Each collection often brought together a wide variety of authors. For example, the Brazilian collections "Biblioteca dos Séculos" [Library of the Centuries] or "Coleção Globo" [Globo Collection], published by Globo, and "Fogos Cruzados” [Cross-fire], published by José Olympio in Rio de Janeiro, include authors such as Montaigne, Laclos, Stendhal, Flaubert, Maupassant, Verlaine, Balzac, Plato, Shakespeare, Fielding, Emily Brontë, Dickens, Nietzsche, Tolstoy and Poe.

Such collections could be very profitable for the publishing houses, as the purchaser of the initial volume in the series was naturally induced to buy the second volume, and so on. It is also a form of introducing an assembly line Fordism into the book industry. The collection may also classify authors in a very different way to that which is conventionally used, and will plan the readers' reception and organize their expectations of the text.

Once the work is translated it becomes part of the national language and culture. The collections launched in Brazil played an important role in establishing the currency of Brazil on the international intellectual market. A number of collections are devoted to Brazilian subjects: "Biblioteca Pedagógica Brasileira” [Brazilian Pedagogical Library], which includes the famous series "Brasiliana" [Brazilian], "Grandes Livros do Brasil” [Great Brazilian Books], "Biblioteca Médica Brasileira” [Brazilian Medical Library], all published by Companhia Editora Nacional, or "Os Grandes Livros Brasileiros" [Great Brazilian Books] published by José Olympio. These collections were published alongside other series made up mostly of translated texts, such as the collections "Paratodos" [Forall], "Terramarear" [Landseaandair], "Biblioteca das Moças" 
[Library for Young Ladies], all published by Companhia Editora Nacional. José Olympio, for example, issued the collections "Documentos Brasileiros" [Brazilian Documents] and "Os Grandes Livros Brasileiros" [Great Brazilian Books] together with other series such as "Rubáiyát, Jóias da Poesia Universal” [Rubáiyát, Gems of World Poetry] or "Fogos Cruzados" [Cross-fire], both mainly made up of translated foreign texts. Martins, for instance, launched the collections "Biblioteca Histórica Brasileira" [Brazilian Historical Library] and "Biblioteca de Literatura Brasileira" [Brazilian Literary Library] alongside a collection labelled "Excelsior," mostly containing translated books.

This period is often called "Golden Age" of the book industry and translation in Brazil and can be contrasted with the open door policies pursued after the downfall of Vargas in 1945, when, with an artificially high exchange rate to please the coffee exporters, books in a number of areas received preferential tariffs, and, in many cases, were actually sold at a lower cost in Brazil than in their country of origin. Right through the 1950s imported books were sold at a preferential dollar rate which ranged from 33\% to $60 \%$ of the official dollar rate, with the result that it was cheaper to import books than paper on which to print books. As translation rights had to be paid at the official dollar exchange rate, it was much cheaper to import a translation made in Portugal than to buy the rights in Brazil and to carry out the translation in Brazil. Obviously, this period slowed growth in the Brazilian publishing industry, particularly in the area of translations, and Brazilian books became too expensive in Portugal.

\section{Monteiro Lobato - "A Nation is made by men and books"}

The one key figure in the development of the Brazilian book industry is José Bento Monteiro Lobato, a writer of fiction, children's books and treatises on bringing a more forward-looking mentality to Brazil, and a publisher, first at Monteiro Lobato e Cia., and then at Companhia Editora Nacional. Lobato was the first publisher in Brazil to attempt to develop a mass market for books and to develop the book industry as a consumer industry. Until Lobato, most publishing was in the hands of Portuguese or French-owned companies, and the target market was very much that of the Francophile middle-class elite.

Lobato's initial success was with Urupês (1918), stories about rural life inspired by his experience as a farm owner near São Paulo, in which he introduced Jeca Tatu, the indolent yokel who represented rural backwardness and ignorance. This was followed by his first collection of children's stories, A Menina do Narizinho Arrebitado [The Girl with the Turned-up Nose] (1921), in which he introduced his cast of children and dolls at the Sítio do Picapau Amarelo [Yellow Woodpecker Farm]. The success of both books was phenomenal and in many ways started the book industry in Brazil. Urupês went into five editions, and the first edition of Narizinho sold 50,500 copies, 30,000 of which were distributed to schools in the state of São Paulo. By 1920 more than half of all the literary works published in Brazil were published by Monteiro Lobato e Cia., and in 1941, 1/4 of all books published in Brazil were produced by Lobato's Companhia Editora Nacional (Koshiyama 1982: 133). Lobato was a major public figure in Brazil from 1918 to 1927 as, in addition to the success of these two books, he wrote a regular column for the influential newspaper O Estado de São Paulo and bought the middle-brow journal, Revista do Brasil. 
Lobato believed that a growing book industry would greatly aid Brazilian development, "Um país se faz com homens e livros" (Koshiyama 1982: 99). People act through knowing the human experience of other people, which is found in the means of communication, especially books, and then acting.

But despite this exaltation of the book, Lobato had a hard-headed commercial attitude to selling books, which he saw as commercial objects which could be sold just as other goods were, in a variety of sales points: "livro não é gênero de primeira necessidade... é sobremesa: tem que ser posto embaixo do nariz do freguês, para provocar-lhe a gulodice" ["Books are not staple products... they are desserts: they must be put under the nose of the customer, to excite his gluttony"] (in Koshiyama 1982: 72); he managed to increase the sales points for his works from 40, the total number of bookshops in Brazil, to 1,200, including chemists and newsstands. He innovated in terms of the visual presentation of the book, and was responsible for much more attractive covers than the dull yellow featureless covers which followed the French fashion.

Lobato stressed the importance that Brazil should give to its own culture. He was always against following the dominant Francophile culture, copying the latest Parisian fashions in art, music and literature. He wanted to open up Brazil to German, Russian, Scandinavian and Anglo-American literatures and translated and adapted such works as Peter Pan, Alice in Wonderland, Robinson Crusoe, Tom Sawyer, Huckleberry Finn and Gulliver's Travels. Lobato's Companhia Editora Nacional, opened in 1925 after the bankruptcy of Monteiro Lobato e Cia., which over-invented in printing presses, also published works by Conan Doyle, Eleanor H. Porter, Hemmingway, H. G. Wells, Melville, Jack London, Steinbeck, and Kipling. Thus Lobato helped to initiate a movement towards the importation of works written originally in English, which would continue right up until the Second World War when English finally ousted French as the major foreign language studied and spoken in Brazil. His publishing companies also published unknown authors, thus democratizing access to the publishing industry, since getting published had usually required the influence of friends in high places or money.

Lobato believed that Brazil should look to the interior, its own folklore and own traditional myths. But the interior of Brazil needed reawakening. Lobato, always the practical man, encouraged vaccination campaigns and improvements in basic sanitary conditions. The government needed to stimulate investment in the interior, and the country people themselves suffer from indolence, characterized in his picture of the idle yokel, Jeca Tatu, who is in total contrast to the idealized rural figures found in the works of José de Alencar.

From 1927 to 1931 Lobato was commercial attaché for the Brazilian government in the US and was greatly impressed by American economic organization and efficiency. He was a great fan of Henry Ford and visited Detroit. Such mass production could be used in the book industry. The way in which the US had taken advantage of its mineral wealth, particularly iron ore, coal and oil, showed Lobato what Brazil might be capable of if the country took the correct steps and developed its own oil industry, rather than leaving it at the mercy of the trusts, especially the Standard Oil Corporation. On his return from the US, Lobato invested all his efforts and capital in oil prospecting in Brazil. However, these plans were foiled by the onset of the hardening of the Vargas dictatorship in 1937 and the advent of the hardline dictatorship 
of the Estado Novo, when all prospecting plans were centralized and placed under the control of the government, and Lobato's financial losses were considerable.

All the children's literature which was available in Brazil when Lobato began writing was written in the Portuguese of Portugal, and the desire to provide stories his own and other Brazilian children could read stimulated Lobato to write texts for his own and all other Brazilian children. Lobato believed in developing the Brazilian language, and that after 400 years of subservience to Portugal, it was now time to definitively break away from Lisbon and develop a separate Brazilian language.

In a 1921 letter he mentions his plans to produce a series of books for children "with more lightness and wit" (Vieira 2001: 146) than the previously published stories organized by Jansen Muller, which he would rework and "improve." Lobato was puzzled by the language used in the Brazilian translations published by the Frenchowned house, Garnier, and remarked "Temos que refazer tudo isso - abrasileirar a linguagem" ["We must redo all of this - Brazilianize the language"] (Koshiyama 1982: 88), and he recommended that the translator Godofredo Rangel take the liberty of improving the original where necessary. Thus Lobato's translation technique is one of adaptation, using a more simplified and colloquial language which could immediately be understood by children, Lobato's target audience.

His adaptation of Don Quijote, Don Quixote das Crianças, clearly shows his adaptation technique: The naughty rag doll, Emília, Lobato's alter ego, takes a thick book off the shelf, a Portuguese translation of Don Quijote, which Dona Benta begins reading to her grandchildren and the dolls. However, they and Dona Benta find the literary style turgid. After hearing "lança em cabido, adarga antiga, galgo corridor” (Monteiro Lobato 1957: 16), Emília, who, like Lobato, is against everything which is old-fashioned and backward, fails to understand anything, loses interest and is ready to go off and play hide and seek. So Dona Benta herself retells the story to the children. This retelling and adaptation also takes place in Peter Pan, while Robinson Crusoe (1930), Gulliver's Travels (1937), Alice no País das Maravilhas [Alice in Wonderland] and Alice no País do Espelho [Alice through the Looking Glass] are adapted with no interventions. Near the end of D. Quixote das Crianças, Pedrinho asks whether his grandmother Dona Benta is telling all the story or just parts, and Dona Benta replies that only mature people should attempt to read the whole work, and that only what will entertain children's imagination should be included in such versions (ibidem, p.152). "Literary" qualities have no place in a work for children, whose imaginations should be stimulated by fluent, easy language. In a 1943 letter, Lobato describes the difficulties he had to

extirpar a "literatura" de meus livros infantis. A cada revisão nova mato, como quem mata pulgas, todas as literaturas que ainda as estragam. O último submetido a tratamento foram As Fábulas. Como achei pedante e requintado! De lá raspei quase um quilo de "literatura" e mesmo assim ficou alguma... (Abramovich 1982: 152)

[get rid of the "literature" in my children's books. With each revision, I kill, just like someone who is killing fleas, all the literatures which are spoiling them. The last one I did was Aesop's Fables. How pedantic and sophisticated it was. I managed to shave off almost a kilo of "literature," but there was still some left...]

In Peter Pan and D. Quixote das Crianças, this intimate contact with the story is emphasized through the interaction the listeners have with the story and the charac- 
ters. Lobato uses the technique of Sherazade, with Dona Benta interrupting the story every night at nine o'clock, bedtime, and promising more entertainment for the next evening. The listeners get caught up with the stories: In Peter Pan, Emília makes a hook to put on her hand. In D. Quixote das Crianças, she dresses up as Don Quijote, and attacks the hens and the cook, saying she is the giant Freston; Pedrinho, Lobato's other alter ego, gets involved in books in the same way as Don Quijote does. After reading the history of Charlemagne, he says that Roldon became incarnated in him as he got an old sword, went to the corn plantation, and, thinking the corn plants were 300,000 moors, cut them all down (Monteiro Lobato 1957: 94-95).

Lobato's work is overtly didactic as he is always inserting his pet themes in the middle of the story. One of the most prominent is that of expanding the book market in Brazil. At the beginning of Peter Pan, the children, Pedrinho and Narizinho, and the doll, Emília, having heard about Peter Pan in As Reinações de Narizinho [The Reigns of Narizinho], ask their grandmother, Dona Benta, who Peter Pan is. As Dona Benta doesn't know, she writes to a bookshop in São Paulo which sends her Barrie's work in English. Lobato thus inserts an advertisement for mail orders for bookshops, and then Dona Benta retells the story to the children and dolls in Portuguese, thus re-enacting in the book the situation of an oral retelling. Pedrinho has also inherited Lobato's entrepreneurial spirit as he intends to set up a toy factory when he grows up, and intends to market a variety of dolls, including copies of those at the Sítio do Picapau Amarelo (Monteiro Lobato 1957: 12).

Lobato introduces vocabulary extension exercises as Dona Benta explains "pigmento (Monteiro Lobato 1971: 22), cinegética [related to hunting] (ibidem, p. 60), "excêntrico" (85), the use of "líquido" in "uma questão líquida" (ibid., p. 59), and "interpolada" (Monteiro Lobato 1957: 190). References to Marie Antoinette (Monteiro Lobato 1971: 30), the etymology of the name of Captain Hook's ship, "Hiena dos Mares" ["Hyena of the Seas"] (ibidem, p.75), the background to Cervantes writing Don Quijote (Monteiro Lobato 1957: 18), the fact that barbers used to work as surgeons (ibidem, p. 100), the explanation of stalactites and stalagmites (Monteiro Lobato 1971: 59), the different formats of books: Folio, in octavo etc. (Monteiro Lobato 1957: 152-3) also broaden the general knowledge of the reader.

Narizinho says she enjoys Peter Pan because it is a modern story, funnier and so different from the traditional stories of Grimm, Andersen, Perrault, with their neverending succession of kings, queens, princes, princesses and fairies, thus reflecting Lobato's attempts to renovate Brazilian children's literature (Monteiro Lobato 1971: 28). Lobato was no friend of the Estado Novo nationalist government of Getulio Vargas which despised him for his internationalism, his constant negative comparisons of Brazil to the US and the UK, his atheism, and his continual meddling. In March 1941 Lobato was accused of sending an insulting letter to dictator Getúlio Vargas, the President of the Republic and the General Gois Monteiro, and was imprisoned for six months, of which he served three, despite considerable protest from intellectuals against his imprisonment.

Lobato's Peter Pan suffered considerable political problems. In June 1941, a São Paulo state public prosecutor, Dr. Clóvis Kruel de Morais, reported to the Tribunal de Segurança Nacional in favour of prohibiting the distribution of Peter Pan as it would give children the wrong opinion of the government of Brazil and gave an impression that Brazil was an inferior country to Britain. 
When the narrator, Dona Benta, compares Brazilian children to English children, she says that, unlike Brazilian children, all English children have a special room of their own, a nursery, which will be full of toys, special furniture and wallpaper. By contrast, the room of the Brazilian child will be "um quarto qualquer e por isso não tem nome especial" (Monteiro Lobato 1971: 59), thus demonstrating the inferiority of living conditions of Brazilian children. Likewise, he compares heating systems. In forward-looking cold countries all houses have central heating, and not an open hearth. Although central heating is not needed in Brazil, it is clearly linked to the "países atrasados" (ibidem, p. 59-60).

A further passage in which Lobato betrays Brazil is when Emília asks whether English children play with a "boi de xuxu," a toy animal made by sticking pieces of wood into a vegetable, common in country areas in Brazil where children had to improvise toys out of odds and ends. One of the main characters of Lobato's children's stories is the doll Visconde, who is made from an old shuck of corn (ibidem, p. 12). Dona Benta replies that English children are very spoilt and are given the toys they want, and that they are not incredibly expensive, as they are in Brazil. Highquality German toys made in Nuremberg are also praised, whereas in Brazil the toy industry is only just beginning. Of course, here, as in the section quoted, Lobato is inserting his opinions against the economic protectionism of Getulio Vargas' Estado Novo government. Another report for the Tribunal de Segurança Nacional [National Security Tribunal], made by Tupy Caldas, accused Lobato's works of being excessively materialistic and lacking any kind of spiritualism, and that they should be banned as dangerous to the national educational programme since they failed to contribute to the formation of a "juventude patriótica, continuadora da tradição cristã, unificadora da Pátria" [patriotic youth, continuing the Christian tradition, and unifying the motherland"]. Vargas himself, aware of the possible role which books could play, underlined this very danger:

Todo e qualquer escrito capaz de desvirtuar esse programa é perigoso para o futuro da nacionalidade. $\mathrm{O}$ nosso mal até aqui foi justamente dar liberdade excessiva aos escritores, quando é o livro o mais forte veículo de educação. (in Carneiro 1997: 76)

[All written matter which may pervert this programme is dangerous for the future of the nationality. Our problem until now has been that we have given excessive freedom to our writers, when the book is the most powerful means of education.]

Both Peter Pan and Don Quijote can be seen as anarchic figures, failing to respect authority. Pedrinho says of Don Quijote: “- O que eu gosto em D. Quixote observou Pedrinho, é que êle não respeita cara. Mêdo não é com ele. Seja clérigo, seja moinho de vento, seja arrieiro, êle vai de lança e espada em cima, como se fôssem carneiros." [What I like in Don Quixote is that he doesn't respect anybody. He's not one to be afraid. Whether it's a priest, a windmill, or a mule-driver, he goes at them with his lance and spear as if they are sheep."] (Monteiro Lobato 1957: 91). Lobato's anti-clericalism was not surprisingly unpopular with the right-wing of the Catholic Church, whose views can be seen in Padre. Sales Brasil's A Literatura Infantil de Monteiro Lobato ou Comunismo para Crianças [The Children's Literature of Monteiro Lobato or Communism for Children] in which he accused Lobato of encouraging the Communist revolution, bad manners within the family, atheism, and rebellion against the right to private property. 
As a result of the instructions given by the Tribunal de Segurança Nacional, the São Paulo Department of Social and Political Order (DEOPS) apprehended and confiscated all the copies of Peter Pan it could find in the state of São Paulo.

\subsection{Lobato and Anthropophagy}

In Lobato's adaptations we see a very important way in which a developing nation like Brazil will use original works from the First World. Lobato adapts the original stories, he changes the original emphasis; in D. Quixote das Crianças he "translates" the original difficult Portuguese into a much simpler and more readable language. Today, he says "usamos a linguagem a mais simplificada possível, como a de Machado de Assis, que é o nosso grande mestre" ["we use the most simplified language possible, like that of Machado de Assis, our great master]. By contrast, Portuguese classical writers used a much richer language and more complex constructions (Monteiro Lobato 1957: 190-1). In Peter Pan Lobato makes comparisons with the Brazilian reality, as, for example, when the North American redskins are compared to Brazilian Indians and comparing them to the caboclos (half-Indians).

In 1928 Oswald de Andrade published the Manifesto Antropofágico, in which he presented the image of the Brazilian cannibal, who would "devour" the enemy, so he could take over his soul. Thus the Brazilian writer, like the cannibal, would not take in the foreign influence in a passive way, but rather by transforming it into something new. The original will be actively swallowed and reproduced in a different form.

Adriana Vieira compares Lobato's "anthropophagy" to that of Haroldo and Augusto de Campos (Vieira 2001: 153). Though Lobato is adapting popular literature within a commercial setting, and the Campos brothers are translating much more erudite non-commercial literature, Vieira believes that both Lobato and the Campos brothers use the original text in an anthropophagic way, adapting the original and putting their own characteristic Brazilian mark on it.

\section{Carlos Lacerda, the "Dethroner" of Presidents}

Lacerda (1914-1977) fame in Brazil is that of the "dethroner" of presidents, having played an important role in the overthrow of at least three presidents: Getúlio Vargas (1954), Jânio Quadros (1961) and João Goulart (1964). Although he was a member of the Brazilian Communist Party (PCB) at the beginning of his political career in 1934, it was as a member of a right-wing party, the National Democratic Union (UDN), that he was elected a Rio de Janeiro city councillor in 1947, a federal deputy in 1955 and governor of the state of Guanabara in 1961. Lacerda was also a journalist on the Diário de Notícias, Diário Carioca, Correio da Manhã, Tribuna da Imprensa and, when in exile in the United States, O Globo and O Estado de São Paulo. He also wrote critical works on Brazilian writers such as Carlos Drummond de Andrade and Érico Veríssimo, wrote plays, short stories and chronicles and, during the 1940s, adapted a number of literary works for the theatre, radio and television in Brazil. As a composer he also partnered important Brazilian popular musicians.

Throughout his career Lacerda always showed an interest in translating. He translated classics such as Tolstoy's The Death of Ivan Illitch and Shakespeare's Julius Caesar, Caractères by La Bruyère (1936, under the pseudonym of Luiz Fontoura) and 
Minha Mocidade [My Early Life] by Winston Churchill (1941), of whom Lacerda was a great admirer. His preference for works which reflect the American liberal democratic tradition can be seen in his translations of $O$ Triunfo [The Triumph] by John Kenneth Galbraith, President Kennedy's economic aide; Em Cima da Hora. Conquista Sem Guerra [Il est moins cinq], a severe critique of growing Soviet influence in the world, by Suzanne Labin (1963); O Bem Amado [Come Blow Your Horn] by Neil Simon, a play performed in 1963 when he was still governor of Rio de Janeiro; the preface of the book Estratégia da Paz [Peace Strategy] by John Kennedy; Do Escambo à Escravidão [From Barter to Slavery] by Alexander Marchant (1943), A Vida de Thomas Jefferson [Life and Letters of Thomas Jefferson] by Francis W. Hirst (1943). Lacerda considered translation a form of relaxation from politics and translated the play, Como Vencer Na Vida Sem Fazer Força [How to Succeed in Business Without Really Trying] by Abe Burrows, on the night of $31^{\text {st }}$ March, the date of the 1964 military coup, "in order to relax from the tension" of having the state Guanabara Palace surrounded by forces loyal to Goulart's government.

\subsection{The "Dethronements"}

In August 1954, a hired killer linked to the Vargas regime made an attempt upon the life of Carlos Lacerda, the bête noire of Vargas, and who was often nicknamed "O Corvo" ["The Raven"] by his detractors. Lacerda was shot in the foot, but his bodyguard, the Brazilian Air Force officer, Major Rubem Vaz, was killed when struggling with the assassin. Lacerda retaliated in his speeches on TV and radio and his articles in his newspaper, the Tribuna da Imprensa, which accused the Vargas government of corruption and harbouring the assassins. Mass anti-government demonstrations took place outside the presidential Palácio do Catete in Rio de Janeiro. The military, who felt their position undermined by an alternative power, Vargas' presidential guard, carried out a full enquiry, arrested the assassin and discovered the crime had been approved by Vargas' inner circle and organized by a member of the Presidential Guard, Gregório Fortunato.

Vargas' position was no longer tenable, and it seemed he would no have option but to resign. However, on the morning of 25th August 1954 Vargas committed suicide with a shot to the heart. Scenes of mass mourning followed, and Lacerda, as the number one critic of Vargas, passed from being victim of the President to the assassin, and had to go into hiding.

In the 1960 General Election, Lacerda and the UDN, mainly supported by business and the middle-classes, supported the populist candidate, Jânio Quadros. However, Lacerda quickly became disillusioned by Quadros's general lack of competence, his inability to get any important bill through an increasingly hostile congress, and, most importantly, his increasing approximation with the Soviet block and China. On 19 August 1961 Che Guevara was received and decorated by Quadros, but no other government ministers attended the ceremony. Lacerda's newspaper, the Tribuna da Imprensa, attacked this decision of Quadros, and Lacerda no longer felt he could support Quadros. Lacerda believed that Quadros intended to close Congress and make a reform in the Constitution which would strengthen the executive powers of the President. On the evening of 24 August 1961, ironically, the seventh anniversary of Vargas's suicide, Lacerda spoke on TV and radio, denouncing Quadros for intending 
to close Congress, refusing to pass government resources to the state government of Guanabara, and his approximation with the Soviet Union and Cuba. Quadros, increasingly isolated from Congress, resigned, gambling that the military officers who supported him would ask him to return and would grant him greater powers. However, his plan backfired, he was not asked to reconsider, and the Vice President, João Goulart, then in China, eventually took over the Presidency.

Though not without enormous difficulty, as Goulart was hated by the highranking military for his left-wing views, and was only permitted to rule through a parliamentary system until 6 January 1963, when a plebiscite voted to return to a presidential system. The year of 1963 and early 1964 saw increasing unrest. Goulart's proposed land reforms were unpopular with the right; it seemed as if Goulart might attempt to replace the presidential system with Cuban-style popular assemblies, and might call off the presidential elections planned for 1965; and there was increasing industrial unrest. Lacerda spoke and wrote against the Goulart government, also translating the anti-Soviet tract Em Cima da Hora: A Conquista sem Guerra [Il est Moins Cinq], by the French author, Suzanne Labin. On 19 March a huge anti-Goulart demonstration, called the "March of the Family with God for Freedom," was held in São Paulo. But the last straw for the military hierarchy was the rebellion by junior naval officers who demanded a relaxation of discipline and greater rights. On 24 March Goulart ordered their release from court-martial, and the officers celebrated in the streets of Rio de Janeiro. This inflamed the majority of military officers, who rebelled on 31 March and officially staged a bloodless coup on 1 April 1964.

Lacerda's official line is that he supported the revolution in order to preserve democracy, fearing that Goulart would introduce a Soviet/Cuban style political system into Brazil, and that presidential elections would soon be held. However, the next presidential elections were all of 25 years away, and the initial relatively moderate military regime headed by General Castelo Branco (April 1964 - August 1967) was followed by the more hardline regimes of Costa e Silva (March 1967 - August 1969) and Médici (October 1969 - March 1974). The Ato Institutional no. 5, 13 December 1968, cracked down on all left-wing groups, introduced severe censorship, and closed down Congress. Many important political and public figures went into exile. Lacerda himself, who was now one of the leading critics of the military regime, lost his political rights.

\subsection{Lacerda's translation of Julius Caesar}

Comparisons with Shakespeare's Julius Caesar can be made with all of the above three cases: the conspiracies in which Lacerda's role was central in changing public opinion; the Presidents who were taking on excessive powers and becoming isolated from the power brokers and public opinion; and the fall out between Lacerda and the military in the post-1964 period.

Lacerda's translation of Julius Caesar was published in 1966, and, therefore, the initial impression is that Lacerda made the translation in order to reflect the 1964 coup. However, the translation was actually carried out in 1955, several months after Vargas's downfall. Lacerda makes specific reference to this, particularly the importance of the Vargas' Carta Testamento: 
"Quando cheguei em casa estava começando o grande erro. O Café Filho assumiu o governo imediatamente, mas largou as rádios de lado. $\mathrm{E}$ as rádios quase todas ainda nas mãos do pessoal do Getúlio de dez em dez minutos se referiam à carta testamento... que era acompanhada com música de fundo, músicas tristes, marchas fúnebres, etc., e lida com a maior ênfase de dez em dez minutos... E o povo começou a sair para a rua, aquela agitação toda. O cadáver de Getúlio exposto, visitado por milhares de pessoas que choravam, gritavam, desfaleciam, que tinham ataques e chiliques." [...] "Diante do clima que se criou de agitação nas ruas e depredações - a Tribuna da Imprensa foi cercada e ameaçada e o povo gritava: "Abaixo a Aeronáutica," "Abaixo os americanos" e "Morram Lacerda e Roberto Marinho de O Globo" ... Aí me levaram de helicóptero para a ilha do governador... onde passei três ou quatro dias."

(Lacerda 1977: 147)

["When I arrived home I could see that the big mistake was already beginning. Café Filho immediately took charge of the government, but he didn't take charge of the radio stations on the presidency. And they were almost all in the hands of Getúlio's people, who, every ten minutes, made references to the carta testamento [...] it was accompanied by background music, sad music, funeral marches, etc., and read with the greatest emphasis every ten minutes. And the people began to come out into the street, all that mess. Getúlio's body was uncovered and was visited by thousands of people who wept, shouted, fainted, who went into fits." [...] "In this tense climate in the streets, there were stonings - The Tribuna da Imprensa was surrounded and threatened, and the people shouted: "Down with the Air Force," "Down with the Americans" and "Kill Lacerda and Roberto Marinho of O Globo" ... Then they took me by helicopter to the Ilha do Governador... where I spent three or four days."]

“... o que tinha acontecido no Brasil era o que aconteceu no drama de Shakespeare, e não foi à toa que traduzi esse drama: Júlio César. A mesma multidão que aclamava Brutus e os que mataram César, quando Marco Antônio fez seu discurso com o cadáver nos braços, começou a pedir a morte dos que tinham assassinado César. [...] Foi assim que passei de vítima a assassino de Vargas [...] Vargas, que num certo momento era, não digo odiado, mas desprezado pela maioria do povo, ao morrer, ou por sentimentalismo, ou por causa desse tipo de exploração, ou ainda por um natural pudor nosso de não continuar a atacar um homem que tinha se suicidado [...] passou a ser o Júlio César de Shakespeare."

(Lacerda 1977: 149)

["What happened in Brazil was what happened in Shakespeare's play, and it wasn't by chance that I translated Julius Caesar. The same mob that acclaimed Brutus and those who killed Caesar, when Mark Antony made his speech with the corpse in his arms, began to demand the death of those who had killed Caesar. [...] This was how I passed from being a victim to the murderer of Vargas [...] Vargas, who, at a certain time, was not exactly hated, but disdained by the majority of people, on dying, or through sentimentalism, or through this kind of exploration, or through a natural reluctance of not continuing to attack someone who has committed suicide [...] became the Julius Caesar of Shakespeare."]

The parallel with Shakespeare's Julius Caesar thus becomes clear. Lacerda's own television and radio speeches and newspaper articles in the days preceding Vargas' suicide are Brutus' speech over Caesar's body, giving his reasons for the assassination of Caesar. Brutus is supported by the Citizens, in the same way that anti-Vargas protesters supported Lacerda and demonstrated outside the Palácio do Catete and elsewhere in Rio de Janeiro against the Vargas government. The Carta Testamento is 
Mark Antony's famous “Friends, Romans, Countrymen” eulogy to Caesar, which is responsible for completely turning the minds of the Citizens against Brutus and the other conspirators so that they are hounded out of Rome. In a similar way, the constant playing of the Carta Testamento on government radio stations, which the Vice President, Café Filho, failed to stop, its considerable rhetorical force, and the support which Vargas, the "father of the poor" had enjoyed particularly amongst the poorer sector of the population, resulted in the tables becoming completely turned. The crowds weeping for Vargas demanded Lacerda's blood, as the Citizens in Julius Caesar demanded the blood of the conspirators, and Lacerda, similar to Brutus and the other rebels fleeing Rome, had to go undercover for a while. ${ }^{1}$

A comparison of the final three paragraphs of the Carta Testamento with a section of the Eulogy will make the link clear, particularly in terms of the references to sacrifice, blood and treason:

Tenho lutado mês a mês, dia a dia, hora a hora, resistindo a uma pressão constante, incessante, tudo suportando em silêncio, tudo esquecendo, renunciando a mim mesmo, para defender o povo, que agora se queda desamparado. Nada mais vos posso dar, a não ser meu sangue. Se as aves de rapina querem o sangue de alguém, querem continuar sugando o povo brasileiro, eu ofereço em holocausto a minha vida.

Escolho este meio de estar sempre convosco. Quando vos humilharem, sentireis minha alma sofrendo ao vosso lado. Quando a fome bater à vossa porta, sentireis em vosso peito a energia para a luta por vós e vossos filhos. Quando vos vilipendiarem, sentireis no pensamento a força para a reação. Meu sacrifício vos manterá unidos e meu nome será a vossa bandeira de luta. Cada gota de meu sangue será uma chama imortal na vossa consciência e manterá a vibração sagrada para a resistência. Ao ódio respondo com o perdão.

E aos que pensam que me derrotaram respondo com a minha vitória. Era escravo do povo e hoje me liberto para a vida eterna. Mas esse povo de quem fui escravo não mais será escravo de ninguém. Meu sacrifício ficará para sempre em sua alma e meu sangue será o preço do seu resgate. Lutei contra a espoliação do Brasil. Lutei contra a espoliação do povo. Tenho lutado de peito aberto. O ódio, as infâmias, a calúnia não abateram meu ânimo. Eu vos dei a minha vida. Agora vos ofereço a minha morte. Nada receio. Serenamente dou o primeiro passo no caminho da eternidade e saio da vida para entrar na História. (Rio de Janeiro, 23/08/54 - Getúlio Vargas)

[I have struggled month after month, day after day, under constant pressure, bearing everything in silence, taking notice of nothing else, renouncing even my own self, in order to defend the Brazilian people, who have now lost their protector. My blood is all I have left to give you. If the birds of prey need the blood of someone, if they must keep on bleeding the people of Brazil, I offer them up my own life in the form of a holocaust.

I have chosen this way to be with you for ever. When they humiliate you, you shall feel my soul suffering at your side. When hunger knocks at your door, you shall feel in your breast my strength to fight for you and your children. When they insult you, you shall feel me helping you to reply. My sacrifice will unite you, and my name will be your flag. Each drop of my blood will be an immortal flame in your conscience and will encourage you to resist. I respond to hatred with forgiveness.

And to those who think that they have defeated me, I respond with my victory. I was a slave of the Brazilian people, and today I enter the freedom of eternal life. But the 
people to whom I was a slave will no longer be the slave of anyone. My sacrifice will remain forever in their soul, and my blood will be the price of their rescue. I fought against the plunder of Brazil. I fought against the robbery of the Brazilian people. I have given all I have. Hatred, insults, slander failed to keep me down. I have given you my life. Now I offer you my death. I have no misgivings. I calmly make the first step on the road to eternity and leave life to enter history.]

If you have tears, prepare to shed them now.

You all do know this mantle: I remember

The first time ever Caesar put it on;

'Twas on a summer's evening, in his tent,

That day he overcame the Nervii:

Look, in this place ran Cassius' dagger through:

See what a rent the envious Casca made:

Through this the well-beloved Brutus stabb'd;

And as he pluck'd his cursed steel away,

Mark how the blood of Caesar follow'd it,

As rushing out of doors, to be resolved

If Brutus so unkindly knock'd, or no;

For Brutus, as you know, was Caesar's angel:

Judge, $\mathrm{O}$ you gods, how dearly Caesar loved him!

This was the most unkindest cut of all;

For when the noble Caesar saw him stab,

Ingratitude, more strong than traitors' arms,

Quite vanquish'd him: then burst his mighty heart;

And, in his mantle muffling up his face,

Even at the base of Pompey's statue,

Which all the while ran blood, great Caesar fell.

$\mathrm{O}$, what a fall was there, my countrymen!

Then I, and you, and all of us fell down,

Whilst bloody treason flourish'd over us.

$\mathrm{O}$, now you weep; and, I perceive, you feel

The dint of pity: these are gracious drops.

Kind souls, what, weep you when you but behold

Our Caesar's vesture wounded? Look you here,

Here is himself, marr'd, as you see, with traitors.

(Julius Caesar, III.ii.)

It is the political act of carrying out the translation, rather than, as in the case of Lobato, changes made in the translations, that is important here. The translation is relatively faithful to the original. Slight changes, however, can be found. Most of them are due to lexical choices and do not add any special meaning: the word "closet" was translated as "gabinete" [cabinet] (Lacerda 1965: 88). In V.v. "Our enemies have bit us to the pit" becomes "nossos inimigos nos arrastam para o fundo" [our enemies drag us to the bottom] (ibidem, p.147). In III.ii. "Caesar has had great wrong" becomes "César causou muita desgraça" ["Caesar caused much misfortune"]. "Countenance" becomes "conduta" [conduct] (ibid., p.16). The most remarkable change is the suppression of V.ii. In addition, there are many other omissions such as in V.iii., where line 43, "Durst I have done my will.," and also, Brutus' final speech "I shall find time, Cassius; I shall find time." were omitted. Other omissions are the last two lines of Cato's speech "A foe to tyrants and my country's friend." and "I am the 
son of Marcus Cato, ho!" in V. iv. and line 21, “Thou seest the world, Voluminius, how it goes.", the end of Brutus' second speech (Lacerda 1965: 147).

Lacerda may have decided to go ahead with publication ten years after carrying out the translation because of the further parallels between the 1964 coup and Julius Caesar. Lacerda was again seen as the main civilian leader of the coup, a Brutus-like figure, and Goulart was now Caesar:

Quando o chefe do Executivo se permite, nas praças públicas, fazer a apologia da subversão e incitar as massas contra os poderes da República que lhe estorvam a marcha para o cesarismo, pode-se afirmar que a ditadura, embora não institucionalizada, é uma situação de fato. (Estado de São Paulo - 14/03/64)

["When, in public, the head of the Executive makes an excuse for subversion and incites the masses against the powers of the Republic which hamper his path towards Caesarism, we can say that the dictatorship, though not institutionalized, is an actual fact.]

Although a brilliant public speaker, highly intelligent and articulate, Lacerda was extremely unpopular in many circles as he was considered to be temperamental, somewhat unstable, untrustworthy and excessively ambitious, unwilling to stop at anything in order to reach his ultimate crown, the Presidency. After the military coup in 1964, his demands that presidential elections be held in 1965, in which he, as the main civilian leader of the coup, would have an outstanding chance of becoming President, and his public criticisms of President Castelo Branco alienated him from many members of this own party, the UDN, and the military leaders. He was never to "dethrone" any of the military leaders. In 1966 he joined ex-Presidents João Goulart and Jucelino Kubitschek to form the Frente Ampla to provide a base for his critiques, but, with the hardening of the regime under the AI-5 (Ato Institucional, no. 5) in December 1968 his political rights were taken away, and the remaining years of his life, until he died in 1977, were spent looking after Nova Fronteira, his publishing company.

\section{Conclusion}

In Translation in a Postcolonial Context and "Translation and Political Engagement," Maria Tymoczko, based on her experience of studying translations and adaptations of the Old Irish legends of Cú Chulainn, describes different ways in which translation can be used for political ends. She emphasizes the way in which these legends were manipulated by Standish O'Grady and Lady Gregory, who cut scatological material and made Cú Chulainn conform more to the Victorian ideal of the medieval knight. These versions, which popularized traditional Irish myths, provided a sense of a national culture and history at the time of the independence movement, and existed alongside more scholarly versions, which emphasized the academic importance of Cú Chulainn legend.

Similar manipulations can be seen in Lobato's adaptations of Peter Pan and Don Quijote, where he inserts his own opinions on education, writing for children, and the economic and political ills of Brazil. Another important point, mentioned by Tymoczko, is that certain texts are chosen with political goals in view (Tymoczko 2000: 41-42). Both Don Quijote and Peter Pan can be seen as anarchic figures, who rebel against what is expected of them in society. 
Lacerda does not manipulate the text itself but attempts to manipulate the politics of the reader by the initial choice of the work to be published, and then by the paratext surrounding this work. His defence of free market liberalism, the reduced role of the state, his enthusiasm for the United States and his rabid anti-communism are reflected in the works he chose to translate. In 1964 he chose to translate Em Cima da Hora: A Conquista sem Guerra [Il est Moins Cinq], by the French author, Suzanne Labin, where he states that the translation had a definite political intention: "Fiel à tese deste livro, creio trazer com a sua traducão uma importante contribuição à luta pela Democracia no Brasil" ["Faithful to the thesis of this work, I believe that by translating it I am making an important contribution to the struggle for Democracy in Brazil" (Labin 1963: 11). His translation will help to stem the growing Communist influence and infiltration in government, education and the military and counterbalance the growing amount of Communist propaganda found throughout Brazil. Then his growing rift with the military can be seen in his postface to his translation of J. K. Galbraith's O Triunfo (The Triumph): "Este livro ajudará, informará o leitor que lerá a última página com a impressão de ter encontrado a resposta para uma das perguntas mais importantes do momento: aonde pode levar essa política de equívocos e desencontros?" ["This work will inform the reader who will reach the last page with the impression of having found the answer to one of the most important questions of the moment: where will this policy of mistakes and conflicts take us?"]; "A primeira edição desse livro saiu exatamente em 1964. No Brasil não houve tempo de aprenderem a lição [...] Agora estão aí os militares [...] Ou se fazem opções necessárias, ou eles as farão - para continuarem no poder [...] A não ser que o sarcasmo de Galbraith se converta em realidade: "por uma vez, o poder da pena foi muito maior do que o da espada." ["The first edition of this work came out in 1964. In Brazil there was no time to learn the lesson [...] Now the military is there [...] Either they take the necessary choices, or they will take the decisions which will keep them in power [...] Unless Galbraith's sarcasm becomes reality: "for once the power of the pen was greater than the sword."]

Lacerda translated Shakespeare's Julius Caesar in order to provide a reflection of Vargas' suicide in August 1954, and his own projection of himself as Brutus, the wronged man with the noble mind, out-maneuvered by the subterfuges and shallow oration of the populists, and then let down and betrayed by his own friends and supporters, a much more attractive image than the popular one of the merciless and hysterical "destroyer" or "demolisher" of President Vargas. And, by the time the translation was published in 1966, further parallels could be made between Presidents Jânio Quadros and João Goulart as images of Caesars who wanted to extend their powers against the will of the people, and Lacerda as the "dethroner" can be read into the translation.

\section{NOTES}

1. The first public performance of Julius Caesar was produced by the São Paulo actress-manager, Ruth Escobar, in 1966 in the Teatro Municipal of São Paulo, and directed by the up-and-coming Antunes Filho. It was an event which divided the Brazilian theatrical world as Lacerda was hated by many people in the artistic world. Escobar managed to get official backing and a star-studded cast, but the play was ill-fated. An excessively complex set prevented rehearsals from being held on the stage, and the dress rehearsal was the first time the cast was together. Only the presence of the business com- 
munity, politicians and military officers at the first night prevented it from being postponed. The performance was calamitous, with the actor playing Caesar injuring his pelvis, constant problems with the set and costumes, and barracking from anti-Lacerda members of the theatrical community. Julius Caesar ran for only one more performance.

\section{REFERENCES}

Abramovich, F. (1982): “Lobato de Todos Nós." In Paulo Dantas (ed.) Vozes do Tempo de Lobato, São Paulo, Traço, pp. 145-157.

Brasil, P.S. (1957): A Literatura Infantil de Monteiro Lobato ou Comunismo para Crianças. Bahia, Aguiar \& Souza.

Carneiro, M. L. T. (1997): Livros Proibidos, Idéias Malditas: O Deops e as Minorias Silenciadas, São Paulo, Estação Liberdade.

Carvalheiro, E. (1982): "Lobato entre a Cruz e a espada: Defesa do seu Amigo e Biográfo," in

P. Dantas, (ed.): Vozes do Tempo de Lobato, São Paulo, Traço, pp. 207-213.

Dulles, J. F. W. (1992): Carlos Lacerda. A vida de um Lutador, Rio de Janeiro, Nova Fronteira, v. 1 1914-1960, v. 2 1960-1977.

Gusmão De Mendonça, M. (2002): O Demolidor de Presidentes, São Paulo, Codex.

Koshiyama, A. M. (1982): Monteiro Lobato: Intelectual, Empresário, Editor, São Paulo, Queiroz.

Labin, S. (1963): Em Cima da Hora, tr. Carlos Lacerda, Rio de Janeiro, Record.

LaCerda, C. F. W. (1977): “Depoimento," Rio de Janeiro, Nova Fronteira.

Landers, V. B. (1982): De Jeca a Macunaíma: Monteiro Lobato e o Modernismo, Rio de Janeiro, Civilização Brasileira.

Mesquita Filho, Júlio de. Leader in Estado de São Paulo, 14 de março de 1964.

Monteiro Lobato, J. (1971): Peter Pan, São Paulo, Brasiliense.

Monteiro Lobato, J. (1957): D. Quixote das Crianças, São Paulo, Brasiliense.

Pagano, A. S. (2001): “An Item Called Books': Translations and Publishers' Collections in the Editorial Booms in Argentina and Brazil from 1930 to 1950," Emerging Views on Translation History in Brazil, CROP, (Journal of the English Language and English and North-American Literature Courses), FFLCH, n. 6. São Paulo: USP, pp. 171-194.

Shakespeare, W. (1966): Júlio César, tr. Carlos Lacerda, Rio de Janeiro, Record.

Shakespeare, W. (1992): Julius Caesar, New York, The Folger Shakespeare Library.

Түмоzско, M. (2000): "Translation and Political Engagement: Activism, Social Change and the Role of Translation in Geopolitical Shifts." The Translator, Volume 6, Number 1, pp. 23-47.

Tyмоzско, M. (1999) Translation in a Postcolonial Context. Manchester: St. Jerome.

Vieira, A. S. (2001): "Monteiro Lobato Translator." Emerging Views on Translation History in Brazil, CROP (Journal of the English Language and English and North-American Literature Courses), FFLCH, n. 6. São Paulo USP, pp. 143-169. 